\title{
Relokasi Hypocentre Gempa Bumi Dengan Velest (JHD) dan Estimasi Sesar Daerah Sumatra Selatan
}

\author{
Irwansyah Ramadhani* dan Bagus Jaya Santosa \\ Departmen Fisika-FMIPA, Institut Teknologi Sepuluh Nopember (ITS), Kampus ITS, Sukolilo, Surabaya, 61111
}

\begin{abstract}
Intisari
Gempa bumi merupakan fenomena alam yang tidak terduga kehadirannya. Dalam magnitude yang besar dapat menimbulkan bencana lainnya yaitu tsunami yang menyebabkan kerusakan infrastruktrur dan korban jiwa. Manusia tidak dapat memastikan kapan bencana gempabumi terjadi, tetapi dapat memperkirakan zona yang rawan akan gempabumi, daerah yang berdampak kerusakan besar, dan perkiraan-perkiraan mengenai waktu terjadinya gempa berikutnya. Cara untuk mengetahui hal tersebut dengan menentukan lokasi pusat gempa (hypocentre) sesungguhnya, model dan karakteristik (sesar maupun patahan) bawah permukaan bumi. Velest merupakan metode JHD (Join Hypocentre Determination) dengan menggunakan banyak event gempa yang diinversi sekaligus (simultan) untuk mendapatkan hypocentre yang sebenarnya. Penentukan model bumi satu dimensi dari velest ini berdasarkan kecepatan gelombang P dan gelombang S. Karakteristik bawah permukaan dilakukan dengan ISOLA yang mampu memberikan gambaran mengenai sesar maupun patahan di suatu daerah. Kedua program tersebut digunakan untuk merelokasi event-event gempa di daerah Sumatra Selatan dan mengetahui karakteristik bumi yang ditentukan melalui momen tensor. Selain dua program tersebut, digunakan algoritma STFT dan CWT untuk analisis gelombang P. Hasil penelitian ini didapatkan metode JHD mampu merelokasi hypocetre gempa serta didapatkannya model bumi 1 dimensi dan momen tensor untuk 4 event menyatakan bahwa pola sesar yang terdapat pada daerah laut Sumatera Selatan merupakan dip-slip.
\end{abstract}

\section{ABSTRACT}

Earthquake is an unpredictable natural phenomena in occurance which has harmfull consequences. In high magnitude, it can cause other disaster i.e. tsunami which result in hard demage infrastructure and loss of population. One can not determine earthquake presence exactly, however can estimate earthquake prone zone, major hard demage zone, and next earthquake presence. They can be estimated through hypocentre determination and earths model. Velest is an JHD ((Join Hypocentre Determination) based method which applies all events to inverted simultaneously and results true hypocentre of earthquake. In other hand, Velest can determine one dimensional earths model based $\mathrm{P}$ and $\mathrm{S}$ wave travel time data. Then, earths characteristic can be determined by ISOLA. It is able to provide an imaging of fault in a research area through moment tensor. Both Velest and ISOLA applies in this research. Arrival time of P wave is analized by STFT and CWT algorithm. Then, Velest applies to earthquake events relocation while ISOLA applies to determine earths characteristic (fault) in Southern Sumatra. This research note that velest is able to determine true hypocentre of earthquake well and one dimensional earth model of South Sumatra. In other hand, moment tensor of 4 events show geometry of fault in Souther Sumatra is dip-slip.

KATA KUNCI: Earthquake, ISOLA, Velest, Momen Tensor, JHD http://dx.doi.org/10.12962/j24604682.

\section{PENDAHULUAN}

Secara geologi, pulau Sumatra terletak diatas lempeng Asia Tenggara yang merupakan pertemuan antara dua lempeng besar dunia, yaitu lempeng Indo-Australia dan lempeng Eurasia [1]. Zona subduksi di wilayah barat daya Sumatra merupakan bagian dari deretan panjang konvergen yang membentang dari Himalaya ke selatan melalui Myanmar, berlanjut ke selatan melewati kepulauan Andaman and Nicobar dan Sumatra, sebelah Selatan Jawa dan Pulau Sunda (Sumba, Timor), dan membungkus kearah utara. Trench ini mengakomodasi pergerakan lempeng Australia menuju lempeng Eurasia. Trench

\footnotetext{
${ }^{*}$ E-MAIL: irwansyahramadhani@yahoo.co.id
}

ini secara umum dikenal sebagai zona subduksi Sunda atau zona subduksi Sumatra [2].

Gunung api aktif di Sumatra terletak sepanjang barisan pegunungan (Gambar 1). Lazimnya, pegunungan ini akan paralel terhadap zona subduksi dan berada di atas kontur kedalaman 100-150 km terhadap subduksi lempeng [3]. Deret pegunungan api ini berlanjut ke arah utara membentuk pulau Barren dan Narcondam sekitar $100 \mathrm{~km}$ di sebelah timur pulau Andaman [2].

Dalam kinematika lempeng, interaksi antara lempeng Indian-Australian dan Eurasia lebih kompleks dibandingkan yang digambarkan pada Gambar 1. Lebih detail, subduksi lempeng Indian-Australian meliputi dua lempeng yang terpisah dan terbatasi, dimana perlahan-lahan mendeformasi daerah sehingga tersubduksi pada trench Sunda. Deformasi internal subduksi lempeng menyebabkan pergerakan beberapa 


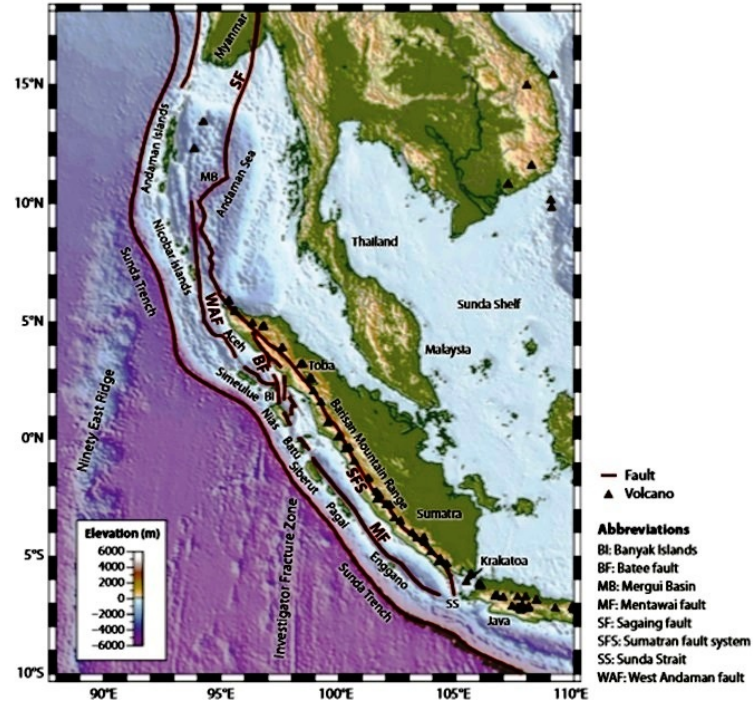

Gambar 1: Fisiografi Pulau Sumatra, terdapat rantai gunung api aktif(segitiga) dan patahan (garis merah) [2]

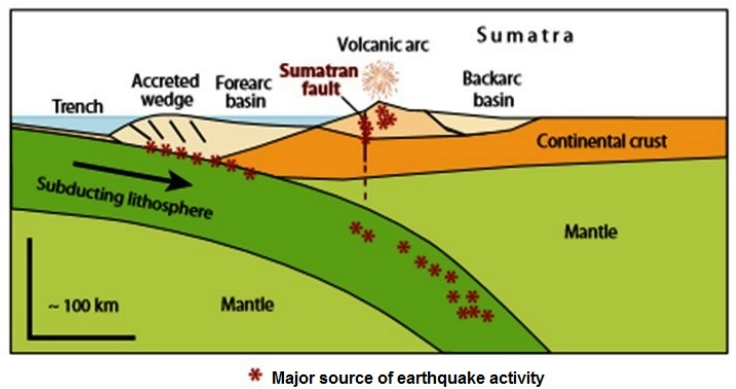

Gambar 2: Cross-section batas lempeng Sumatra [2]

sentimeter per tahun [2].

Deformasi lempeng menyebabkan kompleksitas yang lebih besar dalam pergerakan lempeng. Sumatra yang berada di tepi barat daya lempeng Sunda [4] bergerak beberapa milimeter sampai satu sentimeter per tahun ke timur relatif terhadap lempeng Eurasia. Konvergensi yang dihasilkan antara lempeng Sunda dan lempeng Samudera ke barat daya lebih lambat daripada yang diperkirakan terhadap Eurasia.

Menurut Natawidjaja dan Triyoso [1], patahan Sumatra memiliki potensi bencana yang besar, terutama disebabkan karena populasi penduduk yang besar di sana dan di sekitar zona patahan aktif. Dalam segi aktivitas gempabumi, wilayah Sumatra memiliki berbagai macam sumber yaitu thrust earthquake pada patahan subduksi, strike-slip earthquake pada patahan Sumatra, deeper earthquake di dalam subduksi litosfer, dan volcanic earthquake (Gambar 2). Namun, penyebab gempabumi terbesar berasosiasi dengan subduksi thrust fault, dimana slip pada batas antara subduksi dan overriding plate yang memiliki cakupun wilayah yang luas [1].

Gempa bumi dan segala akibat yang ditimbulkannya adalah fenomena yang sudah dikenal di seluruh dunia. Fenom- ena ini merupakan fenomena yang tidak terduga kehadirannya. Manusia yang merupakan bagian dari alam dapat dimusnahkan oleh alam melalui bencana alam yang dapat dikontrol kejadiannya maupun yang mustahil untuk dikontrol kejadiannya. Salah satu bentuk bencana yang tidak dapat dikontrol dan memusnahkan manusia adalah Tsunami. Tsunami merupakan bentuk dari suatu gempabumi yang terjadi di laut. Gempa bumi terjadi hampir setiap hari, namun belum tentu dapat merasakannya karena bergantung dengan kekuatan gempa. Gempa bumi yang berkekuatan tinggi biasanya terjadi akibat pergerakan internal piring bumi dengan waktu yang menyebabkan kerusakan yang besar. Skala yang digunakan untuk mengukur intensitas dari gempabumi adalah Skala Richter [5].

Gelombang seismik terbagi menjadi dua, yaitu gelombang badan ( $P$ and $S$ wave) dan gelombang permukaan (Rayleigh and Love wave) [6]. Gelombang $\mathrm{P}$ merupakan gelombang yang arah getarannya searah dengan arah rambatnya dan dikenal sebagai gelombang tekan (compressional wave) karena merupakan gelombang longitudinal [7]. Gelombang S merupakan gelombang yang arah getarannya tegak lurus dengan arah rambatannya dimana dikenal sebagai gelombang gelombang geser (shear-wave) karena termasuk gelombang transversal. Pergerakan partikel dari gelombang $\mathrm{S}$ terbagi menjadi dua, yaitu pergerakan dalam arah vertical ( $S V$-Waves) dan pergerakan dalam arah horizontal (SH-Waves) [8].

Gelombang Love merupakan suatu gelombang geser yang merupakan hasil dari interferensi gelombang-gelombang SH. Pergerakan partikel gelombang love sejajar dengan permukaan tetapi tegak lurus dengan arah rambatnya. Gelombang Rayleigh merupakan gelombang yang terbentuk akibat interferensi gelombang P dan gelombang SV [8].

Alat yang digunakan untuk mencatat kejadian gempabumi adalah seismograf. Seismograf terdiri dari dua bagian, yaitu sensor gerak dasar yang dikenal sebagai seismometer dan sistem perekaman seismik. Modern seismometer adalah suatu perangkat elektromekanik yang sensitif namun prinsip dasar pengukuran pergerakan tanah dapat diilustrasikan dengan menggunakan suatu sistem fisika sederhana yang sangat mirip dengan seismogram terdahulu. Seismogram digital merupakan suatu sampel pada suatu interval waktu yang bergantung pada jenis instrumen seismik dan kebutuhan orang-orang yang memanfaatkan seismometer tersebut. Seismogram digital merupakan suatu catatan dari pergerakan tanah yang disimpan sebagai susunan angka yang menunjukkan waktu dan gerakan tanah untuk range waktu tertentu dan dapat dianalisis menggunakan komputer [5].

Untuk merekam pergerakan tanah secara lengkap, maka harus dilakukan perekam gerakan dalam tiga komponen sumbu kartesian. Komponen-komponen yang biasanya dipilih adalah up-down sebagai komponen vertikal, Timur-Barat dan Utara-Selatan sebagai komponen horizontal Richter [5]. Gambar 3 merupakan gambar seismogram pada kedalaman $597 \mathrm{~km}$ pada 23 agustus 1995 di Mariana trench, terekam 1100 dari Harvard, Massachussets. Dapat diketahui bahwa gelombang P dapat terlihat dengan baik pada komponen vertikal, gelombang SV dapat dilihat baik pada arah radial, dan gelombang SH dapat dilihat dengan baik pada komponen 


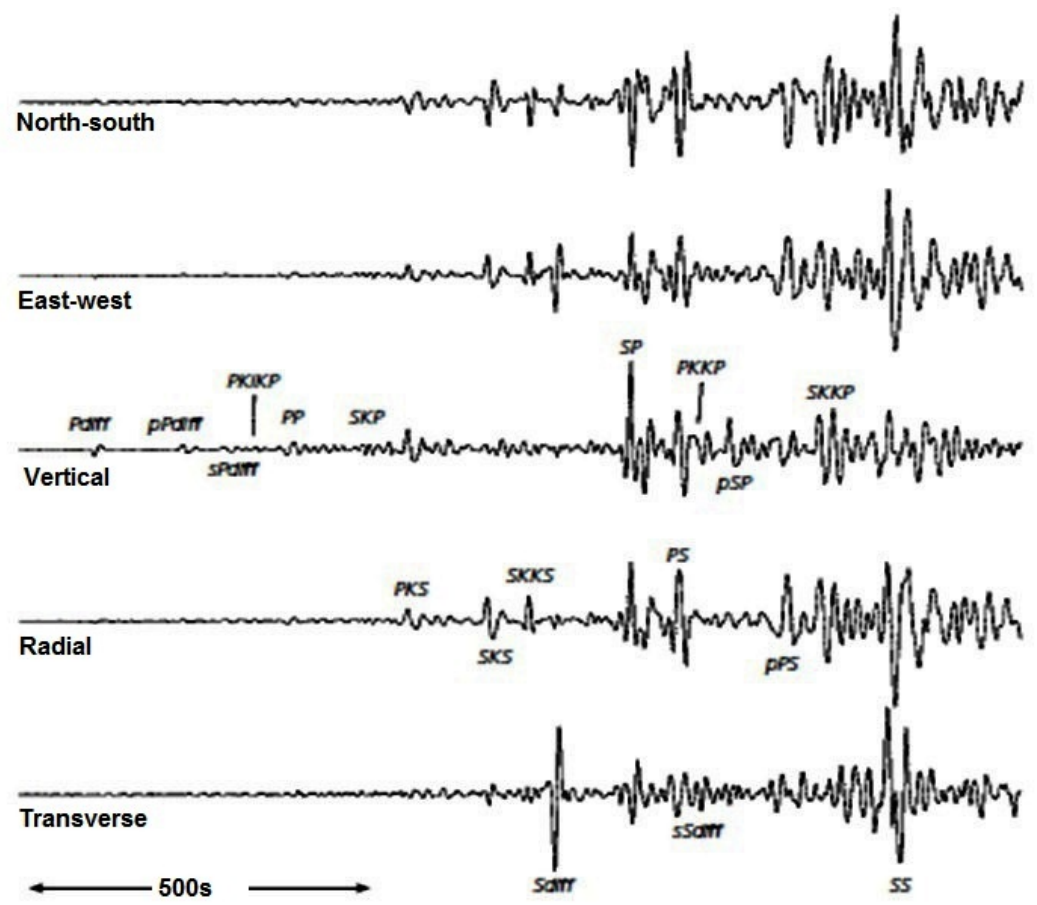

Gambar 3: Komponen Seismogram [9]

transverse.

Gempa bumi akan menghasilkan gelombang $\mathrm{P}$ dan $\mathrm{S}$, dan biasanya gelombang $\mathrm{S}$ akan lebih besar. Gambar 4 menunjukkan tiga komponen dari 2 seismogram yang berbeda ( $U p$ Down, North-South, East-West) dari pergerakan tanah antara dua stasiun seismik Jepang. Gelombang pertama yang datang merupakan gelombang $\mathrm{P}$ yang memiliki perpindahan sepanjang arah penyebarannya dan oleh karena itu akan terlihat jelas pada komponen vertikal. Sedangkan gelombang $\mathrm{S}$ datang kemudian setelah gelombang $\mathrm{P}$, dimana pergerakannya tegak lurus dengan arah penyebarannya sehinga paling jelas terlihat pada komponen horizontal.

Gambar 5 menunjukkan tiga komponen seismogram pada gempabumi dangkal di Vanuatu trench dengan besar gempa 7,7. Berdasarkan Gambar 5, dapat diketahui bahwa gelombang Love dapat diamati dengan baik pada komponen transverse sedangkan gelombang Rayleigh dapat diamati pada komponen vertikal dan radial.

Penentuan suatu hypocentre gempabumi merupakan permasalahan inversi non-linear jika dilihat dari hubungan data dan parameter model. Parameter-parameter yang dibutuhkan dalam penentuan hypocentre gempabumi melibatkan travel time gelombang seismik dan posisi stasiun perekaman [10]. Selain dapat diketahui hypocentre gempabumi, dapat juga diketahui mengenai model buminya. Velest merupakan program yang menggunakan metode JHD (Join Hypocentre Determination) yaitu menggunakan banyak event gempa yang diinversi sekaligus (simultan) untuk mendapatkan lokasi pusat gempa sebenarnya dan sekaligus menghitung model bumi 1dimensi dengan menggunakan koreksi stasiun [11]. Maksud dari penentuan secara bersamaan antara hypocentre gem- pabumi dan model bumi yaitu gempabumi yang terdistribusi dengan baik menyediakan informasi mengenai struktur kerak bumi tanpa menimbulkan permasalahan inheren yang berhubungan dengan intepretasi data.

Geometri dari suatu patahan dapat dideskripsikan dengan mengasumsikan patahan merupakan suatu permukaan planar dimana gerak relatif terjadi selama gempabumi. Geometri patahan dideskripsikan dalam bentuk orientasi bidang patahan dan arah slip sepanjang bidang [9]. Model geometri dari patahan ditunjukkan pada Gambar 6. Bidang patahan dikarakterisasi oleh vektor normal n, sedangkan arah geraknya dikarakterisasi oleh vektor slip d. Vektor slip ini mengindikasikan arah dimana sisi bagian atas dari patahan, dikenal sebagai hanging wall, yang bergerak reltif terhdap sisi bagian bawah, foot wall. Karena vektor slip berada pada bidang patahan, maka arahnya tegak lurus dengan vektor normal. Kordinatkordinat lainnya yang digambarkan pada Gambar 6 membantu dalam studi patahan. Sumbu $\mathrm{x}_{1}$ adalah arah strike yang merupakan perpotongan bidang patahan dan permukaan bumi. Sumbu $\mathrm{x}_{3}$ merupakan titik upward dan sumbu $\mathrm{x}_{2}$ merupakan sumbu yang tegak lurus dengan dua sumbu lainnya. Sudut dip $\delta$ memberikan arah bidang patahan terhadap permukaan [9].

Gambar 7 mendeskripsikan patahan dengan stereonet (beachball). Kuadran hitam dan putih menyatakan compression dan dilatation yang menunjukkan geometri patahan. Empat kuadran checkerboard mengindikasikan gerakan strikeslip pada bidang patahan vertikal. Gerakan menjadi rightlateral jika salah satu bidang adalah bidang patahan dan leftlateral disisi lainnya. 


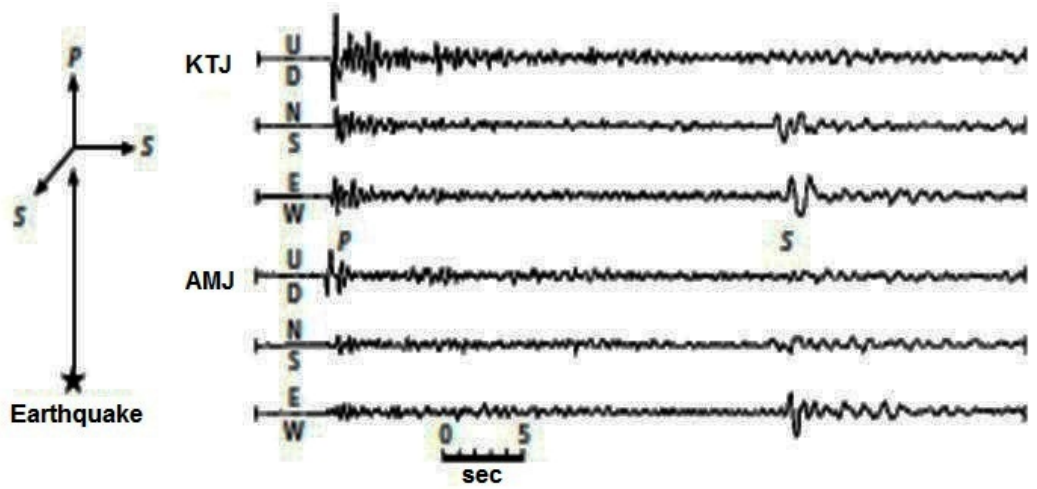

Gambar 4: Komponen 2 Stasiun Seismik Jepang [9]

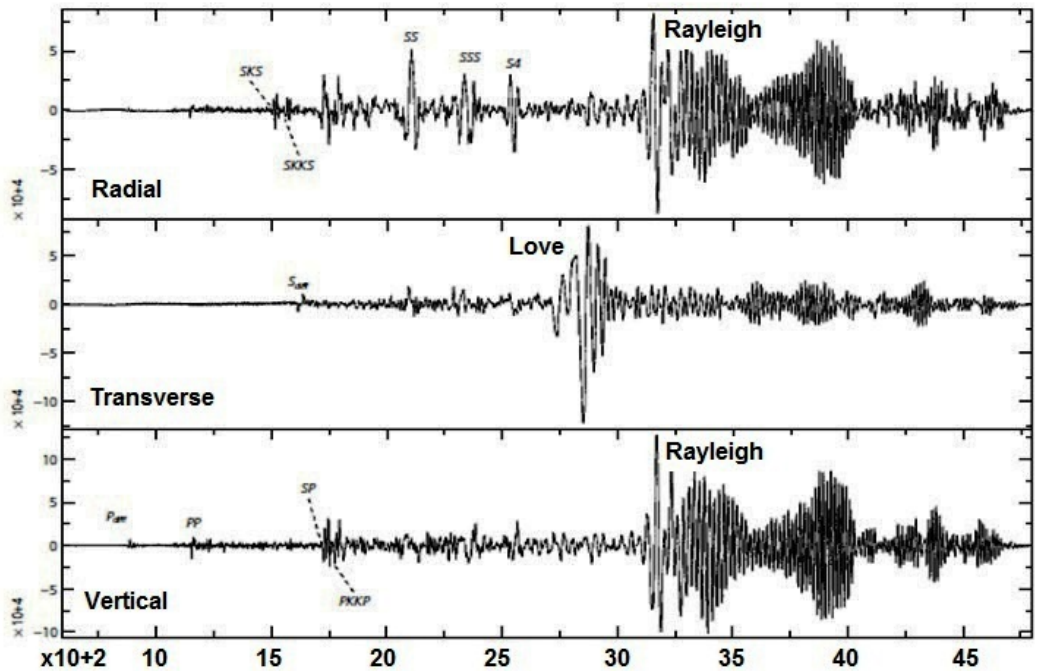

Gambar 5: Komponen Seimogram Gempa Nevada Gambar [9]

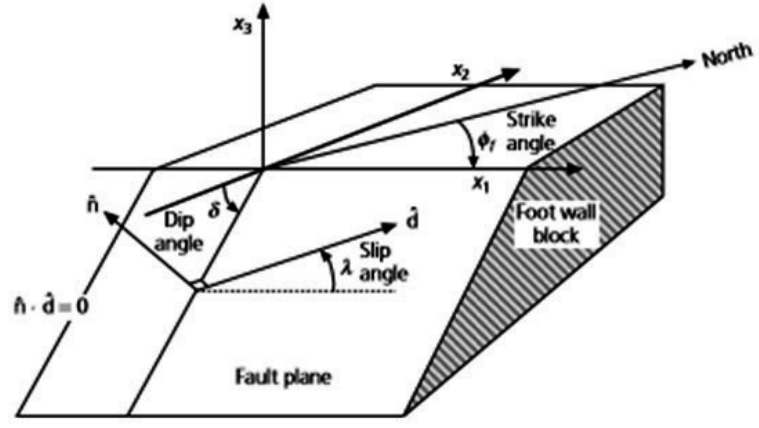

Gambar 6: Geometri patahan [9].

\section{METODOLOGI PENELITIAN}

Penelitian ini bertujuan untuk merelokasi event-event gempa yang telah terjadi sebelumnya di daerah SumatraSelatan menggunakan program velest. Setelah itu, untuk mengetahui karakteristik gempabumi, ditentukan mo-
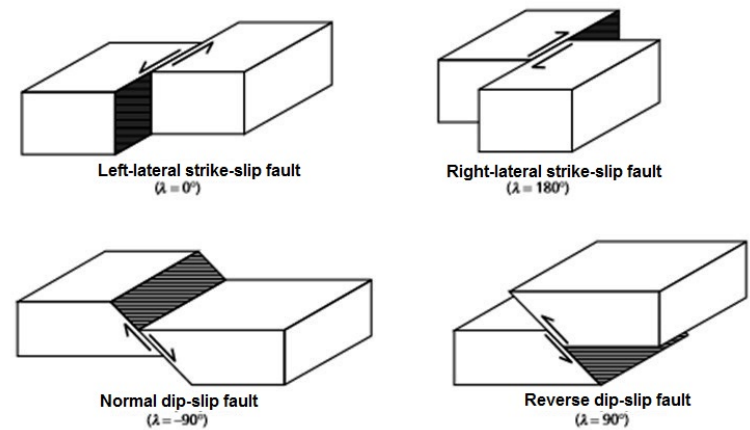

Gambar 7: Jenis-janis dasar patahan [9].

men tensor melalui inversi fungsi green pada program ISOLA. Daerah yang digunakan dalam penelitian ini adalah daerah Sumatra Selatan dengan stasiun perekam yang digunakan diatur berdasarkan letak event yaitu dalam range $0^{\circ}$ sampai $10^{\circ}\left(1^{\circ}=40,075 \mathrm{~km}\right)$ dan informasi gelombang yang dgunakan adalah bentuk gelombang full seed. 


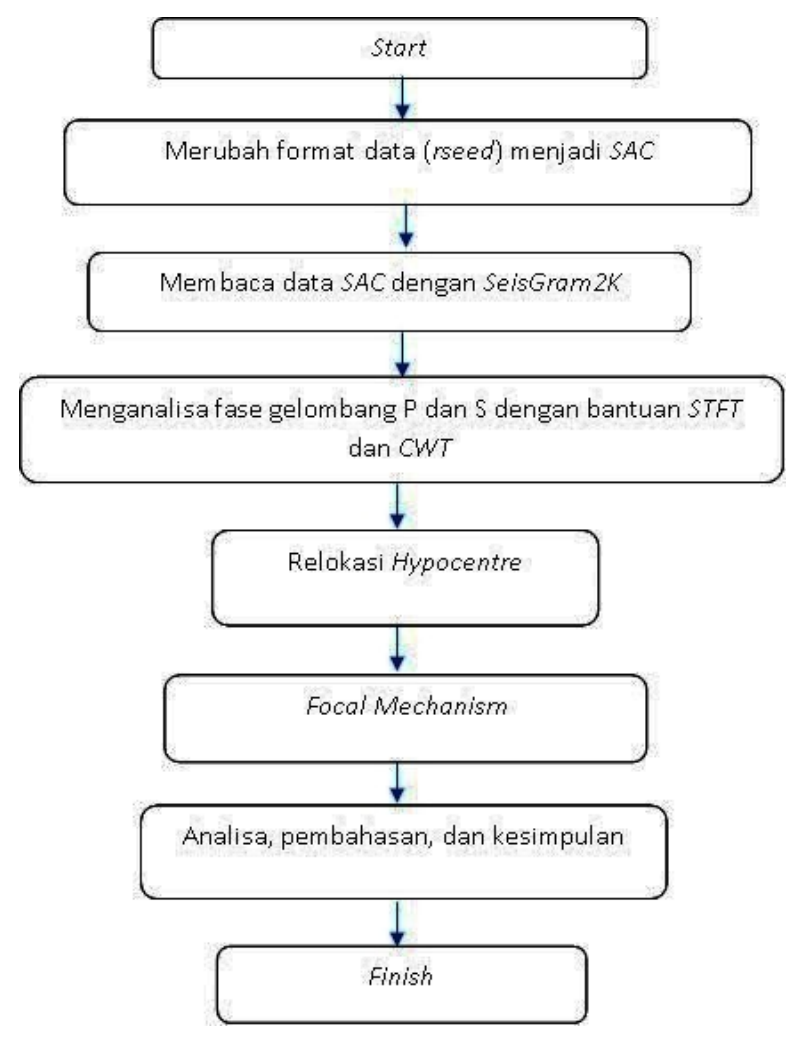

Gambar 8: Flowchart penelitian

Pada penelitian ini, digunakan 5 stasiun dengan 20 event yang berbeda untuk menganalis gelombang P. Data event diperoleh dari website GFZ (GeoForschungsZentrum) http://www.webdc.eu/webdc3/. Flowchart penelitian ini ditunjukkan Gambar 8. Penelitian dimulai dengan analisis gelombang P dengan program SeisGram $2 K$. Selain itu, untuk lebih memastikan mengenai gelombang $\mathrm{P}$ yang akan dipicking, dilakukan analisis STFT (Short Time Fourier Transform) dan CWT Continuous Wavelet Transform.

STFT merupakan teknik yang berdasarkan FFT [12]. STFT adalah suatu metode yang digunakan untuk menganalisis sinyal yang bervariasi terhadap waktu. Namun metode ini mengasumsikan bahwa komponen spektral bervariasi secara lambat sehingga sinyal dapat dianggap stasioner dalam menganalisis time window. Oleh karena itu, STFT tidak memungkinkan perhitungan frekuensi dominan, frekuensi pusat, atau spektral perubahan isi jika perubahan terhadap waktu cepat. Distribusi Waktu frekuensi menggambarkan bagaimana energi didistribusikan dan memungkinkan untuk memperkirakan fraksi dari total energi dari sinyal pada waktu t dan frekuensi $\omega$. Pernyataan di atas menyatakan bahwa energi harus bernilai positif. Untuk mencapai resolusi simultan time-frequency baik dinonstationary time series, maka harus berhadapan dengan prinsip ketidakpastian. Prinsip ketidakpastian membatasi untuk mencapai sembarang resolusi yang baik secara simultan pada domain waktu dan domain frekuensi. Kondisi ini untuk memenuhi prinsip ketidakpastian diberikan oleh

$$
t, \Delta \omega \geq \frac{1}{4 \pi} \cong 0,08 \text { cycle }
$$

dengan pemilihan $\Delta \mathrm{t}$ (resolusi waktu) dan $\Delta \omega$ (resolusi frekuensi) bukan sembarang parameter. Dalam sebagian besar kasus, hal ini bergantung pada karakteristik sinyal [5]. Untuk menghitung STFT continuous-time, fungsi dikalikan dengan suatu fungsi window dengan non-zero hanya untuk periode dan waktu pendek dan kemudian transformasi Fourier dari sinyal hasil diambil.

$$
\operatorname{STFT}_{x}^{g}(w, T)=\int x(t) g(t-T) e^{-i \omega t} d t
$$

g yang umum digunakan adalah fungsi Gaussian [6].

Transformasi wavelet adalah representasi time-frequency yang mengatasi kekurangan STFT. Beberapa sifat wavelet $\left(\psi(x)^{\prime}\right.$ s) adalah

- $\left(\psi(x)^{\prime} s\right)$ mengalami peluruhan hingga ke nol pada $\pm \propto$

- $\psi_{k}(\mathrm{x})=\psi(\mathrm{x}-\mathrm{k})$ untuk $\mathrm{k} \in \mathrm{Z}$

- $\psi_{a, b}(\mathrm{x})=\sqrt{\frac{1}{2}} \psi\left(\frac{x-b}{a}\right)$ untuk $\mathrm{a}, \mathrm{b} \in \mathrm{R}$

Dalam sifat-sifat diatas, $\left(\psi(x)^{\prime}\right.$ s) disebut sebagai mother wavelet. Setiap $\mathrm{f}(\mathrm{x})$ dalam $\mathrm{L} 2(\mathrm{R})$ dapat dinyatakan dalam wavelet series

$$
f(x)=\sum_{m=-\propto}^{\propto} \sum_{m=-\propto}^{\propto} c_{m, k} \psi_{m, k}(x)
$$

dengan

$$
c_{m, k}=\int f(x) \psi_{m, k}(x) d x
$$

Dalam transformasi wavelet, resolusi frekuensi menjadi bagus secara sembarang pada frequensi rendah sementara resolusi waktu menjadi bagus secara sembarang pada frekuensi tinggi [6].

Setelah dilakukan picking gelombang $\mathrm{P}$, maka langkah berikutnya yaitu relokasi hypocentre. Pada bagian Velest, langkah-langkah pentingnya yaitu:

1. Parameter-parameter event yang dimasukkan adalah origin time, latitude, longitude, magnitude, depth, dan hasil picking gelombang $\mathrm{P}$ dan $\mathrm{S}$

2. Parameter-parameter stasiun yang digunakan adalah lattitude dan longitude

3. Kemudian digunakan model kecepatan bumi CALAVERAS 1 dimensi

4. Data-data hasil program velest yang dihasilkan adalah posisi (longitude, lattitude, dan depth) hypocentre, model kecepatan bumi, dan koreksi stasiun. 


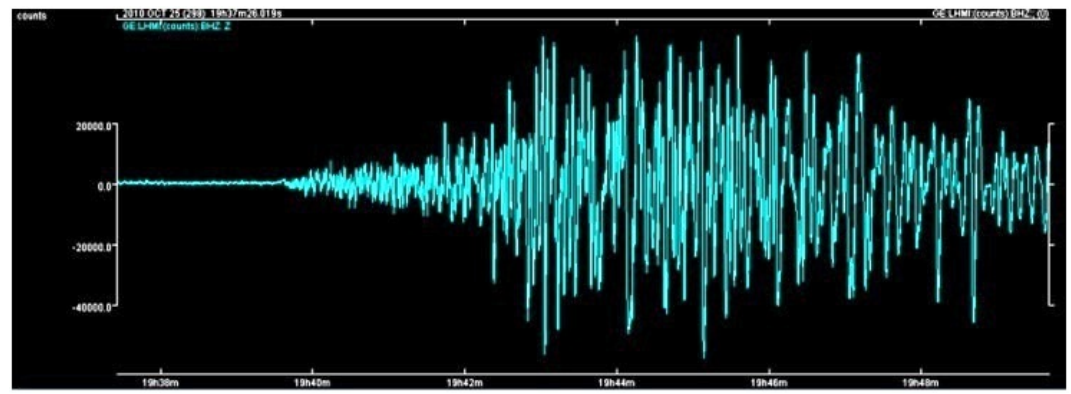

Gambar 9: Analisis gelombang P pada komponon-z stasiun LHMI event 1
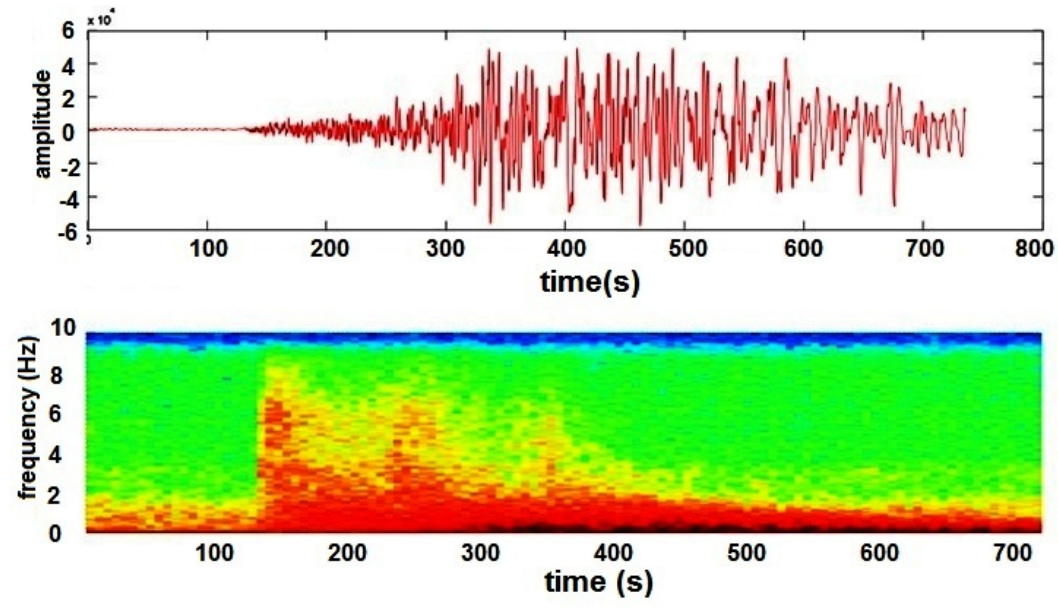

Gambar 10: Analisis STFT

Setelah dilakukan proses relokasi hypocentre, maka berikutnya dilakukan analisis focal mechanism di daerah penelitian. Pada bagian analisis focal mechanism, terdapat beberapa proses-proses penting, yaitu:

\section{SAC IMPORT}

Pada tahap ini, dilakukan import data SAC dari event yang digunakan. Pada tiap stasiun, dimasukkan masing-masing komponennya yaitu data BHE, BHN, dan BHZ. Pada tahap ini, origin time untuk tiga komponen stasiun disamakan.

\section{Define Crustal Model}

Pada tahap ini, didefinisikan model bumi meliputi kecepatan gelombang $\mathrm{P}$ dan $\mathrm{S}$ serta densitas model bumi.

\section{Event Info}

Pada tahap ini, dimasukkan info-info mengenai event yang diteliti meliputi longitude, latitude, depth, origin time, starting time, magnitude, dan time window.

\section{Station Selection}

Pada tahap ini, dilakukan pemilihan stasiun-stasiun yang merekam data event yang digunakan

\section{Raw Data Preparation}

Pada tahap ini, dilakukan koreksi data dan origin align yang merupakan data event yang terekam oleh 3 komponen pada masing-masing stasiun.

\section{Seismic Source Definition}

Pada tahap ini, dilakukan penentuan sumber gempa di bawah episenter dengan mendefinisikan kedalaman awal, spasi kedalaman, dan jumlah sumber.

\section{Green Function Computation}

Pada tahap ini, akan dilakukan perhitungan fungsi green yang merupakan tahap inversi. Fungsi green merupakan sifat elastic dan non elastic dalam suatu medium.

\section{Inversion}

Pada tahap ini, dilakukan inversi waveform tiga komponen yang dilakukan dengan metode dekonvolusi. Pemilihan frekuensi sangat menentukan hasil yang didapatkan yang nantinya akan ditunjukkan oleh nilai variance reduction. Jika nilainya mendekati 1 , maka berasosiasi dengan misfit yang kecil yaitu berhimpitnya data sintetik dan data inversi

\section{Plot Result}

Pada tahap ini, ditampilkan hasil data riil dengan data sintetik. Plot ini akan menunjukkan fitness data real dengan data sintetik. Selain itu, hasil focal mechanisms yang di nyatakan oleh momen tensor yang disertai mengenai informasi parameter gempa.

10. Hcplot

Pada tahap ini, akan didapatkan hasil berupa orientasi 

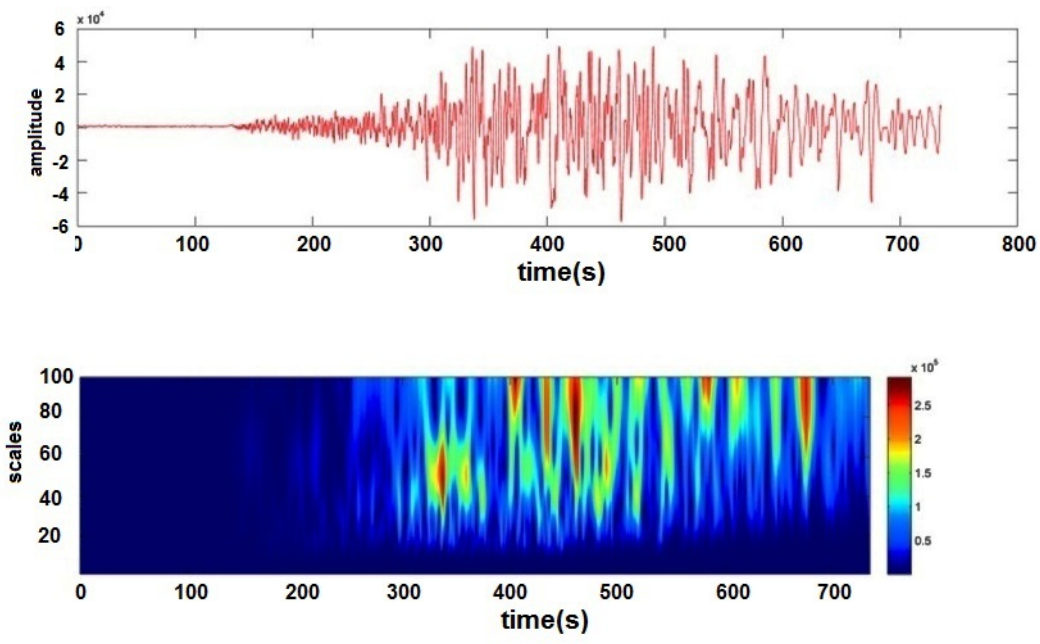

Gambar 11: Analisis CWT

bidang patahan yang berasosiasi dengan momen tensor.

\section{ANALISIS DATA DAN PEMBAHASAN}

Berdasarkan Gambar 9, dapat dilakukan picking gelombang $\mathrm{P}$ secara langsung karena gelombang P memiliki karakteristik yaitu berada pada saat awal getaran terekam. Namun dalam baberapa kasus, gelombang P tidak dapat dilihat secara langsung. Ini merupakan permasalahan krusial karena penentuan gelombang $\mathrm{P}$ harus benar-benar tepat supaya menghasilkan relokasi yang bagus. Oleh karena itu, perlu dilakukan analisis tambahan menggunakan analisis frekuensi, yaitu STFT (Gambar 10) dan CWT (Gambar 11).

Analisis time-frequency dapat menjadi pilihan alternatif untuk menyelesaikan permasalahan komponen-komponen sinyal yang terpisah dalam domain waktu maupun frekuensi. Salah satu analisis time-frequency adalah SFFT. STFT merupakan suatu metode yang berbasis Fourier Transform yang digunakan untuk mengamati sinyal yang bervariasi terhadap waktu (domain waktu). STFT ini akan memberikan hubungan antara waktu dan frekuensi. STFT dapat mengenali komponenkomponen sinyal lebih baik dibandingkan metode FFT selama komponen-komponen sinyal tersebut tidak saling tumpangtindih sehingga dapat diketahui gelombang $\mathrm{P}$ dan gelombang S dalam suatu data rekaman gempabumi [13]. STFT tidak membiarkan suatu frekuensi yang dominan menutupi frekuensi yang tidak dominan, tidak menghitung nilai tengah suatu frekuensi, dan tidak mengubah isi spektrum sehingga memudahkan dalam pengamatan data. STFT dapat mencapai suatu resolusi time-frequency secara simultan dengan baik dalam suatu gelombang yang non-stasioner. STFT digunakan untuk menghasilkan spektrogram. Spectrogram merupakan suatu representasi dari time-frequency yang sangat penting di mana untuk pemrosessan sinyal yang bervariasi terhadap waktu, seperti data gempabumi, dalam 2 dimensi [14]. Secara spesifik, spektrogram dirancang untuk memproses sinyal yang bervariasi terhadap waktu karena secara bersamaan in- formasi yang berasal dari waktu dan frekuensi mendemonstrasikan dimana frekuensi terjadi pada suatu waktu atau di mana waktu yang tepat terjadinya suatu frekuensi. Spectrogram mengkombinasikan informasi yang ada di waktu dan frekuensi dengan menampilkan sinyal pada bidang timefrequency. Dalam spektrogram, format window yang digunakan adalah format 'hann' dengan overlap sebesar 50\% dari ukuran window yang digunakan. Ukuran overlap ini tidak boleh lebih besar dibandingkan ukuran window yang digunakan. Spectrogram akan menghasilkan power spectral density (PSD) untuk masing-masing segmen.

CWT merupakan metode yang digunakan untuk menangani kekurangan pada metode SFFT. CWT memberikan representasi time-scale yang lebih detail dibandingkan dengan STFT. CWT dari suatu time series menyediakan pembagian series kedalam komponen-komponen skala yang berbeda, misalnya memisahkan sinyal kedalam sekolompok sinyasinyal. Representasikan sinyal yang sama namun semua sinyal berhubungan terhadap pita frekuensi yang berbeda. Dapat dialokasikan suatu rentang frekuensi untuk masingmasing komponen skala. Wavelet yang diskalakan dan diterjemahkan dari suatu panjang waveform yang berhingga disebut sebagai induk wavelet. CWT memberikan pemetaan timescale yang dikenal sebagai scalogram, bukan spektrum timefrequency. CWT memungkinkan memperoleh ekspansi yang berbasis ortonormal dari sebuah sinyal dengan menggunakan fungsi time-frequency yang disebut wavelet, yang mampu untuk melokalisasi dalam domain waktu dan frekuensi.

Setelah dilakukan analisis gelombang $\mathrm{P}$, kemudian dilakukan relokasi untuk event-event gempa menggunakan program velest. Program velest menggunakan metode JHD dimana inversi dilakukan secara simultan / bersamaan untuk semua event serta dapat ditentukan model bumi 1-dimensi. Model bumi yang digunakan dalam penelitian ini untuk mendapatkan model bumi pada daerah penelitian adalah model bumi 1 dimensi CALAVERAS (Gambar 12 dan Tabel I) dimana semakin bertambahnya kedalaman, semakin cepat gelombangnya akibat bertambahnya densitas lapisan terhadap 
TABEL I: Model bumi 1-dimensi CALAVERAS.

\begin{tabular}{cccc}
\hline \hline $\begin{array}{c}\text { Depth of } \\
\text { layer top }(\mathrm{km})\end{array}$ & $\begin{array}{c}\mathrm{V}_{p} \\
(\mathrm{~km} / \mathrm{s})\end{array}$ & $\begin{array}{c}\mathrm{V}_{s} \\
(\mathrm{~km} / \mathrm{s})\end{array}$ & $\begin{array}{c}\text { Density } \\
\left(\mathrm{g} / \mathrm{cm}^{3}\right)\end{array}$ \\
\hline 0 & 4.70 & 2.750 & 2.794 \\
1 & 5.50 & 3.220 & 2.800 \\
3 & 5.60 & 3.280 & 2.900 \\
5 & 5.70 & 3.330 & 2.940 \\
10 & 5.80 & 3.390 & 2.996 \\
15 & 6.00 & 3.510 & 3.040 \\
20 & 6.50 & 3.800 & 3.050 \\
25 & 8.00 & 4.680 & 3.300 \\
30 & 8.05 & 4.710 & 3.300 \\
\hline \hline
\end{tabular}

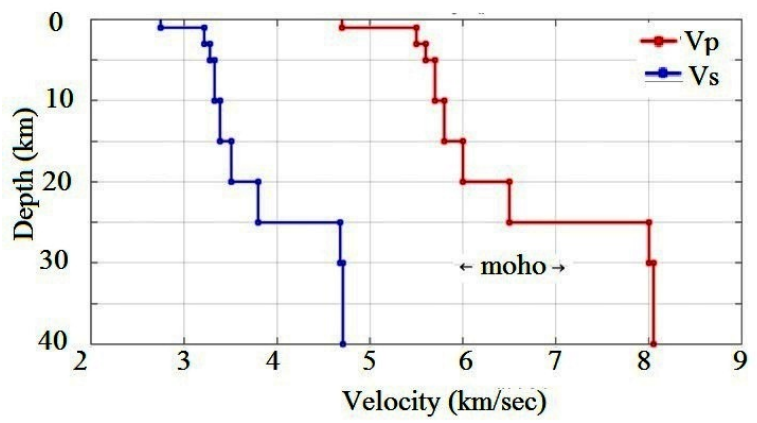

Gambar 12: Model kecepatan bumi 1 dimensi CALAVERAS

kedalaman.

Hasil relokasi ditunjukkan pada Gambar 13, dan dapat dilihat bahwa hasil relokasi dengan menggunakan velest terlihat cukup baik karena hampir sama posisinya dengan data eventevent awal. Solusi dari metode hypocentre-velocity model menghasilkan relokasi hypocentre, model kecepatan bawah permukaan, dan koreksi untuk masing-masing stasiun. Hasil yang cukup baik dengan metode velest dikarenakan metode JHD melakukan inversi secara simultan untuk semua event dan juga menghasilkan model bumi 1 dimensi. Inversi secara simultan ini akan meminimumkan error karena RMSmisfit dari perbedaan waktu tempuh dengan meninjau kombinasi hasil hypocentre, model kecepatan bumi, dan koreksi stasiun. Selain dari Gambar 13, untuk melihat ketepatan relokasi lebih teliti maka dapat dilihat dari residu masing-masing event (Tabel II). Untuk model bumi 1-dimensi, dapat dilihat pada Tabel III dan Gambar 14.

Berdasarkan Tabel II, dapat dilihat bahwa residu untuk masing-masing event sudah cukup baik yaitu kurang dari $10 \%$. Namun terdapat satu event, yaitu event 2 yang memiliki nilai residu sekitar $13 \%$. Hal ini dapat disebabkan oleh ketidaktepatan dalam menetukan gelombang P sehingga hasilnya juga memiliki residu yang besar.

Kemudian, untuk event 1, 2, 15, dan 16 dilakukan analisis momen tensor untuk mengetahui karakteristik bawah permukaan seperti sesar dan patahan. Focal mechanism ini dapat menggambarkan arah gaya tensor terhadap suatu event gempa yang terjadi. Selain itu, jika dilakukan analisis dari beberapa event gempa di wilayah yang sama dalam selang waktu yang berbeda, maka akan didapatkan pola bidang sesar pada

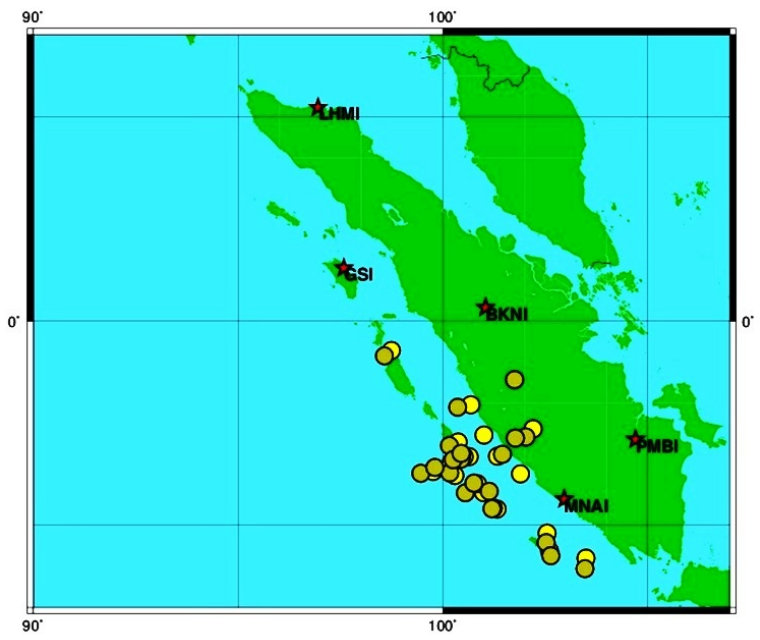

Gambar 13: Relokasi Hypocentre menggunakan program Velest ( sebelum (kuning tua) dan sesudah ( kuning))

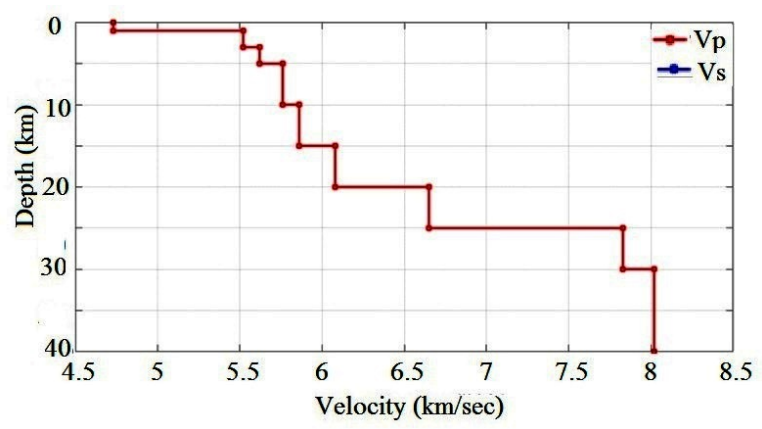

Gambar 14: Model kecepatan bumi 1 dimensi Sumatra Selatan

TABEL II: Hasil relokasi hypocentre dan nilai rms masing-masing event setelah direlokasi.

\begin{tabular}{|c|c|c|c|c|c|}
\hline \multirow{2}{*}{$\begin{array}{l}\text { Event (Southern } \\
\text { Sumatra) }\end{array}$} & \multicolumn{2}{|c|}{ Sebelum Relokasi } & \multicolumn{2}{|c|}{ Setelah Relokasi } & \multirow{2}{*}{$\begin{array}{c}\mathrm{Rms} \\
(\%)\end{array}$} \\
\hline & Latitude & Longitude & Latitude & Longitude & \\
\hline $2010-1$ & -2.96 & 100.37 & -3.0488 & 100.1561 & 0.989 \\
\hline 2011 & -2.79 & 101 & -1.4357 & 101.7472 & 13.2 \\
\hline & -2.64 & & -2.8 & 243 & 0.637 \\
\hline & & & -3.2 & & 0.670 \\
\hline 2010 & & 9 & -4.2045 & 100.5456 & 6.565 \\
\hline & -3 & & -3.7170 & 62 & 0.576 \\
\hline & & & 28 & & 1.415 \\
\hline & & & -3.3 & 08 & 1.463 \\
\hline & & & -5.4 & & 1.165 \\
\hline & .02 & & -5.7408 & & 1.910 \\
\hline & -5.8 & & -6.0552 & 553 & 1.850 \\
\hline & & & -2.8 & 662 & 4.828 \\
\hline & -4.58 & & -4.5933 & 937 & 0.903 \\
\hline & -3.68 & & -3.7251 & 586 & 1.982 \\
\hline & -2 & & -2.1107 & 583 & 1.991 \\
\hline & -3 . & & -3.5 & & 5.620 \\
\hline & & & -4.1 & & 1.050 \\
\hline & & & -3.9 & & 0.954 \\
\hline & & & -3.3 & 189 & 0.637 \\
\hline $2010-0-25$ & -3.29 & 100.46 & -3.2397 & 100.4430 & 0.644 \\
\hline
\end{tabular}




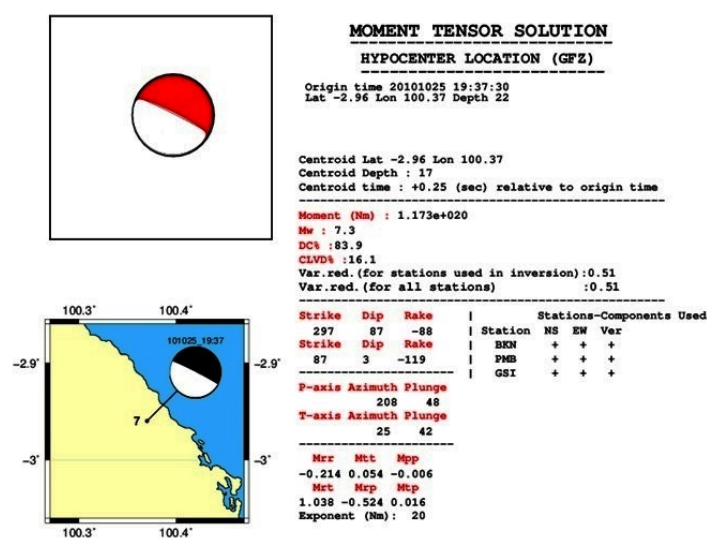

(a) event 1

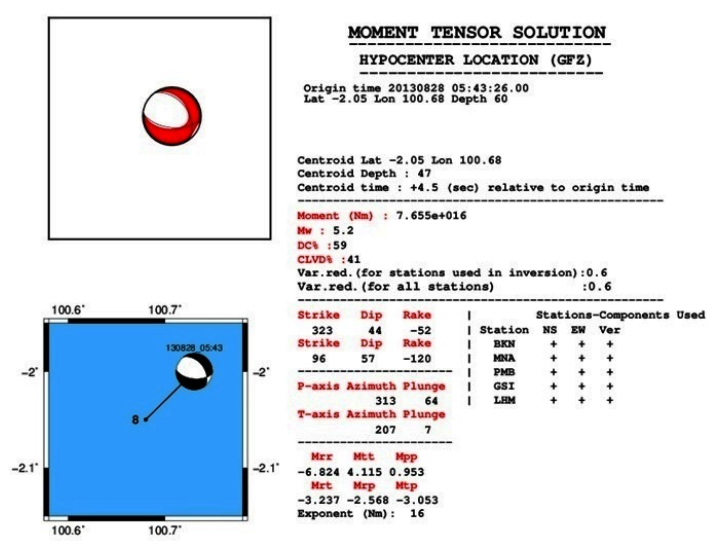

(c) event 15

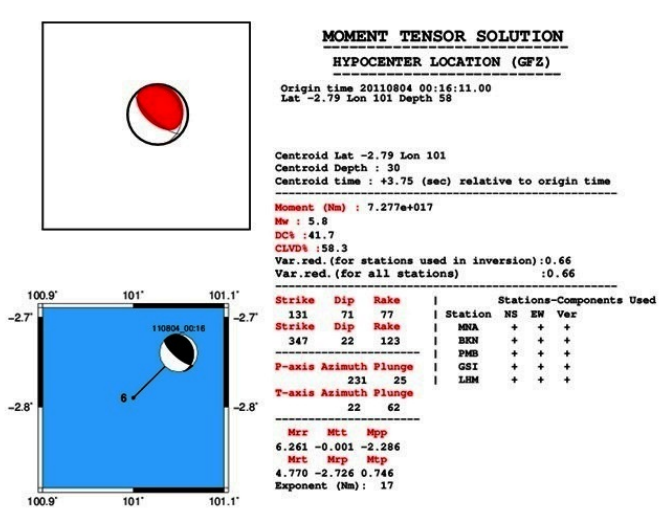

(b) event 2

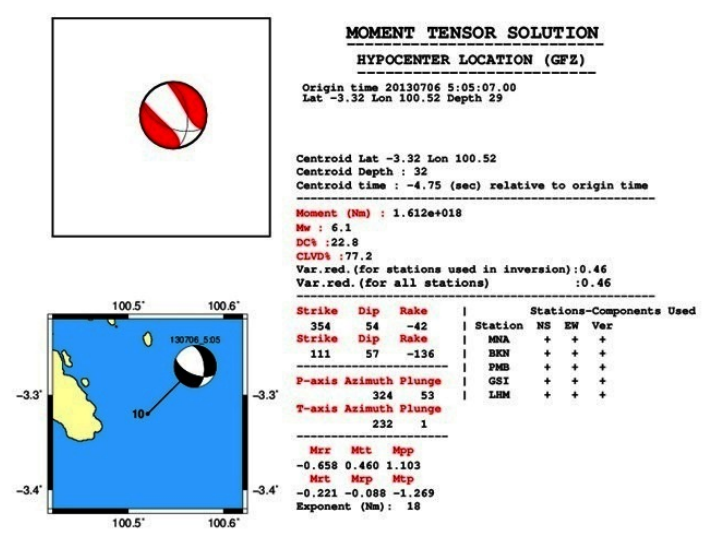

(d) event 16

Gambar 15: Momen tensor

TABEL III: Model bumi 1-dimensi Sumatra Selatan.

\begin{tabular}{ccc}
\hline \hline Depth of layer tp $(\mathrm{km})$ & $\mathrm{Vp}(\mathrm{km} / \mathrm{s})$ & Density $\left(\mathrm{g} / \mathrm{cm}^{3}\right)$ \\
\hline 0 & 4.73 & 2.804 \\
1 & 5.52 & 2.824 \\
3 & 5.62 & 2.852 \\
5 & 5.76 & 2.872 \\
10 & 5.86 & 2.996 \\
15 & 6.08 & 2.916 \\
20 & 6.65 & 3.03 \\
25 & 7.83 & 3.266 \\
30 & 8.02 & 3.304 \\
\hline \hline
\end{tabular}

daerah penelitian. Hasil dari momen tensor untuk event 1 ditampilkan pada Gambar 15. Berdasarkan Gambar 16 mengenai jenis focal mechanism, diketahui bahwa jenis sesarnya adalah vertical dip slip. Cara untuk membaca bentuk dari beachball yaitu dilihat dari masing-masing kuadran yang muncul. Untuk compressional quadrant ditandai dengan warna merah dan dilatation quadrant dengan warna putih. Untuk beach ball yang menampilkan 4 kuadran, umumnya terdapat sesar dip-slip dan strike-slip. Namun apabila hanya terdapat 3 kuadran, maka yang terjadi hanyalah sesar dip-slip. Pada event 2, diketahui bahwa jenis sesar yaitu dip-slip dengan beberapa strike-slip.
Sedangkan untuk event 15 dan 16, diketahui jenis sesarnya yaitu dip-slip dengan beberapa strike-slip.

Dari tahap inversi, dapat dilihat kesesuaian data perhitungan antara data observasi dan data sintetik. Kesesuaian atau yang disebut sebagai fitness data ini menggambarkan kefittan data observasi dan sintetik. Fitness ini berasosiasi dengan nilai error kecil sehingga kurva data riil vs data sintetik akan berhimpitan. Kesesuaian ini juga akan berakibat pada ketepatan bentuk moment tensor untuk masing-masing event.

Setelah diketahui bentuk focal mechanism, maka dapat diketahui orientasi bidang patahan. Untuk orientasi bidang patahan beach ball ditunjukkan pada Gambar 17. Pada orientasi bidang patahan event 1 (Gambar 17(a)), dapat diketahui bahwa bidang berwarna hijau merupakan bidang patahan dan bidang yang berwarna merah merupakan bidang auxilary yang merupakan bidang yang tegak lurus bidang patahan. Orientasi bidang patahan tegak lurus dengan bidang auxilary. Arah orientasi patahan event 1 yaitu barat laut-tenggara, event 2 (Gambar 17(b)) arahnya barat laut-tenggara, event 3 ((Gambar 17(c))), arahnya barat laut-tenggara dan event 4 ((Gambar 17(d))) berarah utara-selatan. Kemudian, peta seismisitas yang berisi sesar hasil proses ISOLA ditampilkan pada Gambar 18 . 


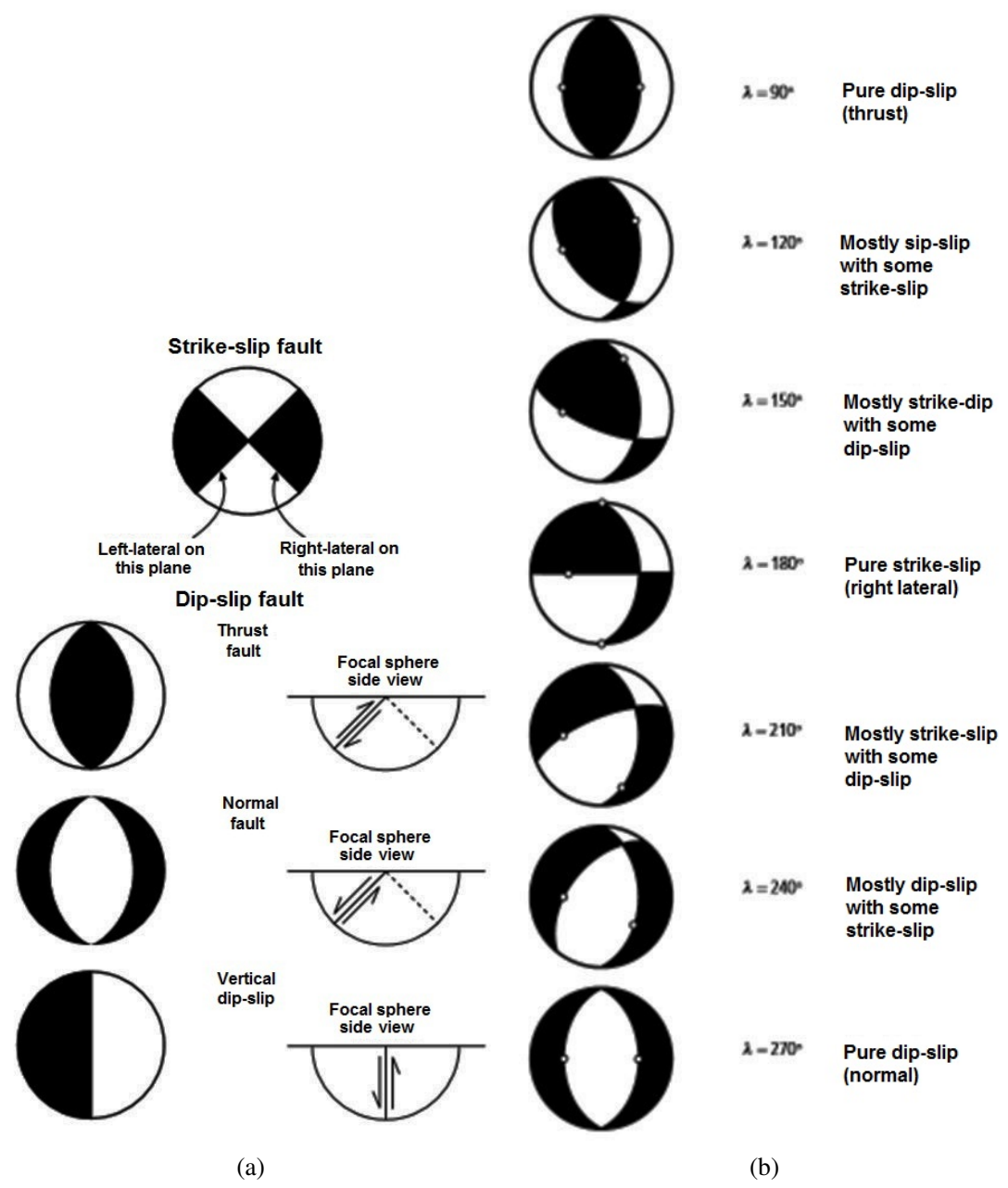

Gambar 16: Focal Mechanism untuk sudut slip $45^{\circ}$ (kiri) dan $90^{\circ}$ (kiri bawah) serta sudut slip yang beragam (kanan) [9].

\section{SIMPULAN}

Relokasi hypocentre hasil program velest yang merupakan program JHD mampu untuk merelokasi hypocetre gempa dengan baik yang dapat dilihat dari nilai rms untuk masing- masing event dan didapatkan model bumi 1 dimensi. Selain itu, hasil momen tensor untuk 4 event menyatakan bahwa pola sesar yang terdapat pada daerah laut Sumatera Selatan merupakan dip-slip.
[1] D.H. Natawidjaja, and W. Triyoso, J. Earthq. Tsunami, 1, 21-47 (2007).

[2] R. McCaffrey, Annu. Rev. Earth Planet. Sci., 37, 345-366 (2009), doi:10.1146/annurev.earth.031208.100212

[3] K. Sieh, and D.H. Natawidjaja, J. Geophys. Res., 105, 28295326 (2000).

[4] P. Bird, Geochem. Geophys. Geosyst, 4, 1-52 (2003).

[5] P. Sarin, and P. Dabas, International Journal of Computer Science and Information Technologies, 7(2),893-895 (2016).

[6] S. Azadi, and A.A. Safavi, S-transform based P-wave and $S$ wave arrival times measurements toward earthquake locating, in Control, Instrumentation and Automation (ICCIA), 2nd International Conference on. IEEE, 241-246 (2011).

[7] R. Simm, and M. Bacon, Seismic amplitude: an interpreter handbook (Cambridge University Press, Cambridge, New York, 2014).

[8] D. Pei, Modeling and inversion of dispersion curves of surface waves in shallow site investigations, ProQuest (2007).

[9] S. Stein, and M. Wysession, An introduction to seismology, earthquakes, and earth structure (Blackwell Pub, Malden, MA, 2003).

[10] H. Grandis, Pengantar Pemodelan Geofisika (HAGI, Jakarta, 2009).

[11] E. Kissling, U. Kradolfer, H. Maurer, Program VELEST user's guide-Short Introduction, Inst. Geophys. ETH Zurich, 1995.

[12] W. Astuti, et al., Adaptive Short Time Fourier Transform (STFT) Analysis of seismic electric signal (SES): A comparison of Hamming and rectangular window, in Industrial Electronics 


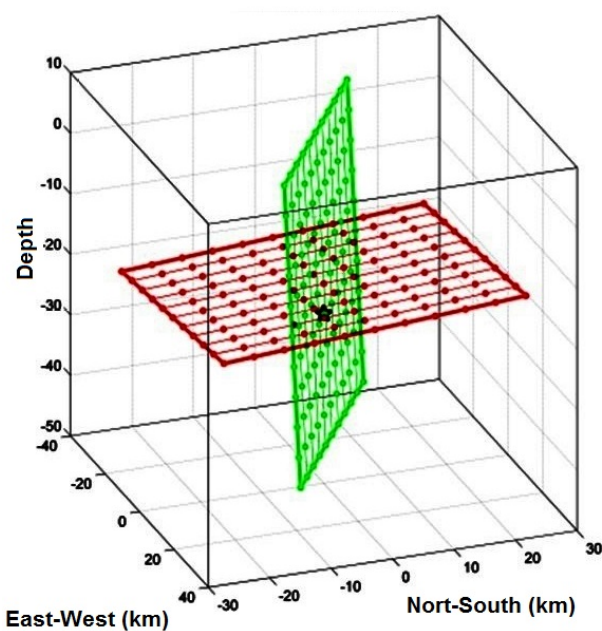

(a)event 1

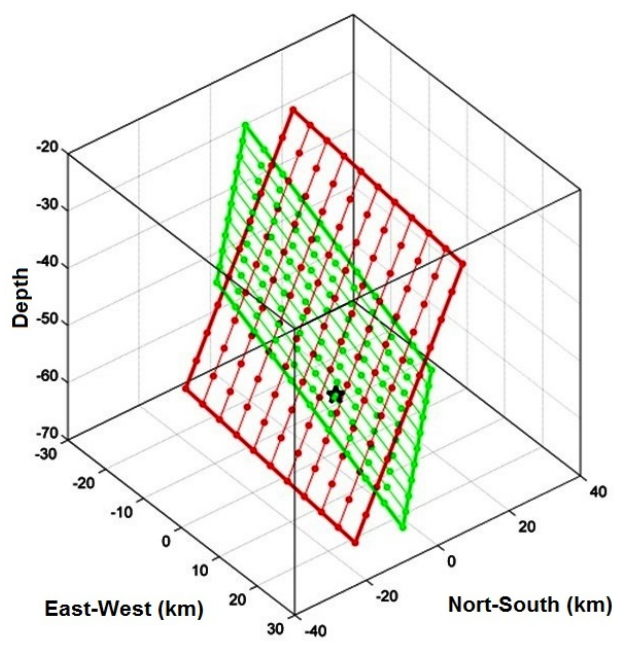

(c)event 15

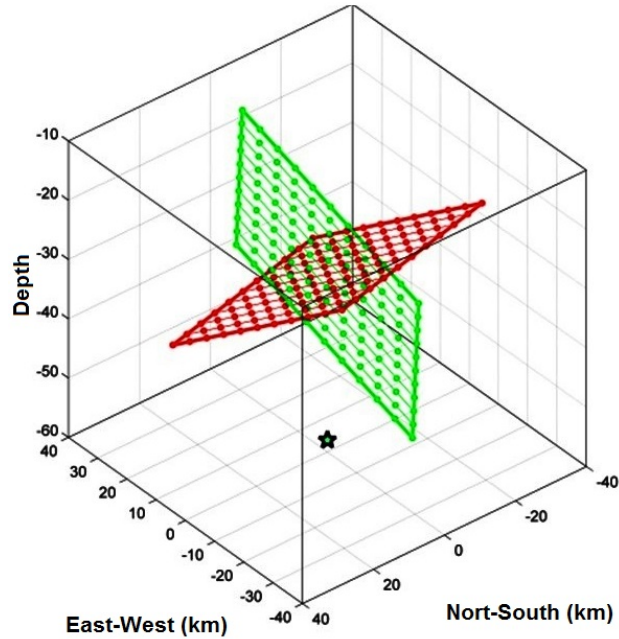

(b)event 2

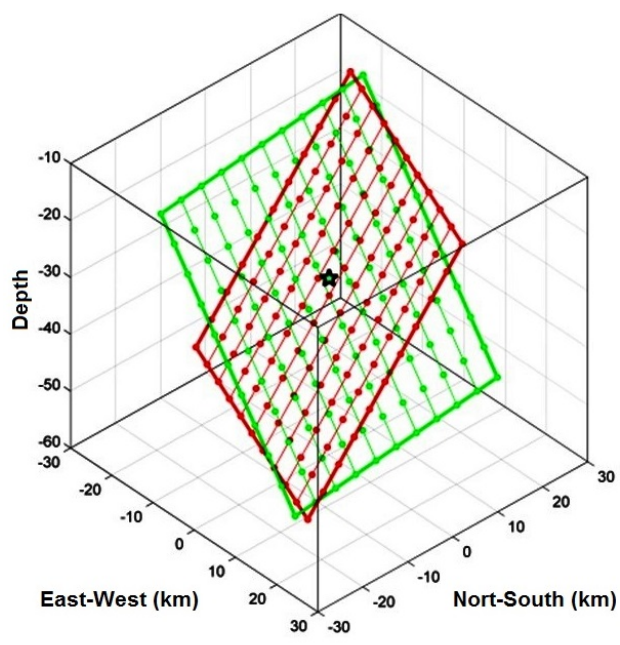

(d)event 16

Gambar 17: Orientasi bidang patahan.

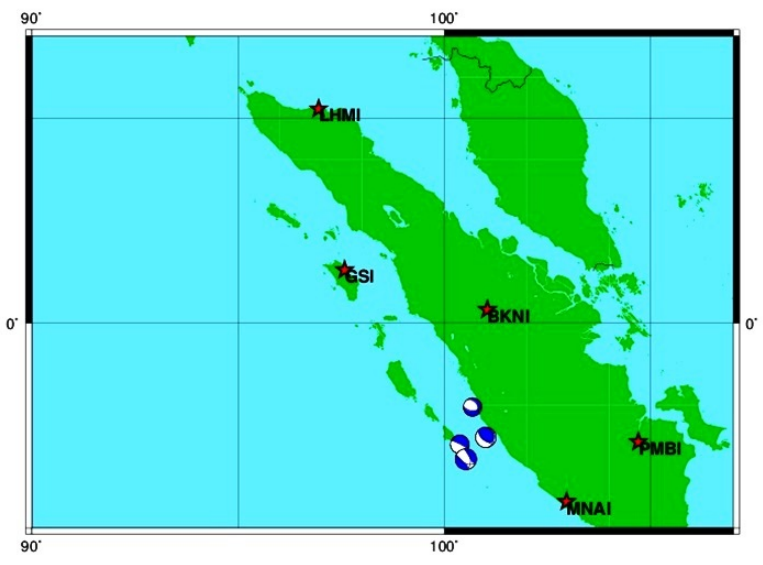

Gambar 18: Peta Seismisitas Sumatra Selatan. and Applications (ISIEA), IEEE Symposium on. IEEE, 372-377, 2012.

[13] R.H. Herrera, et al., IEEE Geosci. Remote Sens. Lett., 12, 364368 (2015), doi:10.1109/LGRS.2014.2342033

[14] H.A. Nofal, et al., Near optimum detection of the p-wave arrival using the spectrograms, in Electrical, Electronic and Computer Engineering, ICEEC'04. 2004 International Conference on. IEEE, 710-715, 2004.

[15] C.I. Huerta-Lopez, et al., Time-frequency analysis of earthquake records, in 12th World Conference on Earthquake Engineering, Auckland, 2000. 